\title{
PENANAMAN PENDIDIKAN NILAI-NILAI MULTIKULTURAL DALAM PEMBELAJARAN SEJARAH KELAS XI DI SMA ISLAM BAWARI PONTIANAK
}

\author{
Desi Andari, Agus Sastrawan Noor, Andang Firmansyah \\ Program Studi Pendidikan Sejarah FKIP Untan Pontianak \\ Email: desiandari088@gmail.com
}

\begin{abstract}
Indonesia is widely known as a multicultural country. This very complex diversity makes Indonesia a culturally diverse country. Multiculturalism in Indonesia should put aside SARA (ethnicity, religion, race, and between groups). Therefore, a multicultural understanding of diversity must always be applied in the learning process. Through historical education which is related to the formation of national character by prioritizing different cultural values. This study aims to find out and get accurate information about the cultivation of multicultural values education at SMA Islam Bawari Pontianak. This research used qualitative research method with sampling purposive technique. The results showed that cultivation of multicultural values education has been applied in the learning process through historical education by inserting multicultural-based values can create the harmony and communion outside and inside the school environment and the high tolerance attitude of students and other school members.
\end{abstract}

Keywords : Multicultural, Historis Learning, Education

\section{PENDAHULUAN}

Negara Kesatuan Republik Indonesia memiliki berbagai keunikan. Salah satunya karena memiliki berbagai suku, agama, ras dan aliran kepercayaan. Leo Suryadinata (dalam Tilaar, 2004). Menuliskan terdapat 20 suku bangsa terbesar. Etnis Jawa merupakan etnis terbanyak dengan jumlah penduduk 83,9 juta jiwa $(41,7 \%)$, diikuti etnis Sunda 31 juta $(15,4 \%)$, etnis Madura, Melayu, Batak, Minangkabau, Betawi, Bugis, dan Banten masing-masing berjumlah sekitar 4-7 juta, atau sekitar (2\%-4,5\%) jumlah populasi manusia.

Keberagaman yang ada di Indonesia sejatinya harus dimaknai dengan bijak dan penuh dengan kedewasaan serta seharusnya mengesampingkan Suku, Agama, Ras dan Antar Golongan (SARA). Dengan keberagaman yang ada, seringkali golongan mayoritas beranggapan bahwa suatu golongan tertentu yang paling bagus, bahkan terkadang merasa paling dominan dan berakhir dengan tindakan menindas golongan minoritas.

Salah satu wilayah di Indonesia yang pernah terjadi konflik antar etnis adalah Kalimantan Barat. Adapun konflik yang terjadi antara etnis Dayak dan Madura. Berdasarkan hal tersebut, Mahmud (2014: 4) beranggapan bahwa dengan adanya konflik tersebut perlu dikembangkannya sikap dan pemahaman tentang multikulturalisme. Multikulturalisme sendiri merupakan suatu pemahaman atau cara pandang yang erat kaitannya dengan memperhatikan interaksi antara kebudayaan satu dengan yang lainnya secara sama atau setara (Mahfud, 2014: 4).

Anggapan tentang satu golongan lebih baik dari golongan lainnya seharusnya dihilangkan. Cogan (yang dikutip dalam Hakim, 2018: 1) mengemukakan bahwa "Karakteristik 
warga Negara yang baik adalah warga Negara yang memiliki kemampuan untuk memahami dan menerima perbedaan kebudayaan, kemampuan berpikir kritis, mampu menyelesaikan konflik tanpa kekerasan, kemampuan bekerja sama dengan orang lain, dan kemampuan berpartisipasi dalam kehidupan politik lokal, nasional, dan global".

Rasa saling menghormati dan menghargai antar sesama golongan mesti ditingkatkan agar tidak ada lagi perselisihan antara suku atau golongan. Jika telah muncul rasa saling hormat dan menghargai antar sesama golongan maka akan tercipta kerukunan dalam kehidupan sehari-hari. Keberagaman juga memberikan dampak bagi bangsa Indonesia. Keberagaman juga memberikan dampak bagi bangsa Indonesia. Akan menjadi penguat jika dikelola dengan baik dan menjadi pemecah bila tidak didasari oleh kesadaran tentang pentingnya hidup bersama.

Dalam konteks perpecahan, kompleksnya keberagaman dapat menyebabkan Indonesia rawan konflik dibandingkan dengan Negara-negara lain. Salah satu kasus yang pernah terjadi di Indonesia khususnya seperti yang ada di Kalimantan Barat sehingga membuat dua suku yaitu Dayak dan Madura bersitegang dan dampaknya masih terasa hingga saat ini. (Mahfud, 2014: 4). Melihat hal tersebut penting bagi masyarakat mengembangkan sikap dan pemahaman tentang multikulturalisme. Multikulturalisme adalah pandangan seseorang yang menekankan hubungan dengan memperhatikan keadaan setiap kebudayaan dan entitas yang memiliki hakhak yang sama.

Karena hal itulah dalam memahami multikulturalisme dengan baik, maka perbedaan yang ada merupakan sebuah fakta yang tidak dapat dihindari. Perbedaan yang ada ini tentu harus dihargai dan dihormati dalam derajat yang sama sehingga nantinya tidak adanya pemikiran atau sikap merasa paling dominan antara kebudayaan satu dengan kebudayaan lainnya. Sayangnya, pemahaman dan sikap tersebut tidak dapat serta merta dilahirkan begitu saja, tetapi perlu ditanamkan dan diwariskan serta diajarkan sejak dini yang salah satunya bisa dilakukan melalui pendidikan (Wibowo, A.M, 2018).

Pengembangan kewarganegaraan dan kebudayaan bangsa Indonesia dengan corak masyarakat yang plural, ditandai dengan kenyataan adanya ikatan sosial yang berdasarkan suku bangsa, agama, adat serta kedaerahan. Berdasarkan pandangan John Gray, (Liliweri 2005: 67) tentang pluralisme mengatakan bahwa pluralisme dapat mendorong perubahan bagaimana cara berpikir monokultural berubah menjadi cara berpikir multikultural.

Setelah mengetahui pengertian dari multikulturalisme sebagaimana yang telah dijabarkan di atas, maka penting untuk mengetahui pengertian daripada Pendidikan Multikulturalisme, mengingat pentingnya menanamkan sikap multikulturalisme bagi penerus bangsa. Pendidikan multikultural (multicultural education) adalah sebuah cara yang bisa diterapkan dan digunakan dalam bidang pendidikan dengan memanfaatkan keberagaman latar belakang kebudayaan yang ada di lingkungan sekolah sebagai bentuk kekuatan untuk membentuk dan membangun sikap multikultural. Pendidikan multikultural juga dilandasi dengan adanya gagasan filosofis yang erat kaitannya dengan kebebasan, keadilan, kesederajatan, serta perlindungan terhadap hak-hak manusia. Pendidikan multikultural sejatinya bertujuan untuk menjadikan siswa bersama-sama secara aktif untuk mewujudkan kesamaan struktur organisasi dan lembaga sekolah yang ada di sekolah.

Berdasarkan Conrad P Kottak dalam buku Ngainun Naim \& Achmad Sauqi (2011: 123-125) ada setidaknya tujuh karakteristik khusus kultur, yaitu :

a. Kultur adalah sesuatu yang general dan spesifik sekaligus. General dapat diartikan sebagai setiap manusia di dunia ini pasti mempunyai budaya. 
Sedangkan spesifik itu sendiri artinya kultur pada kelompok masyarakat sangat bervariasi dan bergantung pada kelompok masyarakat di mana kultur tersebut berada. Jadi kesimpulannya adalah pada dasarnya setiap orang memiliki budaya yang telah dibawa dan diterapkan dalam kehidupannya sehari-hari.

b. Kultur adalah sesuatu yang dipelajari.

c. Kultur adalah sebuah simbol. Simbol pada umumnya dapat terbagi menjadi dua bentuk, yaitu bentuk verbal dan bentuk non verbal atau dalam bentuk bahasa yang khusus.

d. Kultur dapat membentuk dan melengkapi sesuatu yang alami. Secara alamiah manusia harus makan.

e. dan mendapatkan energi, kemudian kultur mengajarkan pada manusia untuk makan makanan jenis apa, kapan waktu makan, dan bagaimana cara makan. Kultur pada dasarnya dapat menyesuaikan setiap manusia dengan keadaan alam secara alamiah dimana kita hidup.

f. Kultur merupakan sesuatu yang dikerjakan secara bersama-sama yang menjadi atribut bagi seseorang dari kelompok masyarakat.

g. Kultur adalah sebuah model. Artinya adalah kultur bukan merupakan sekumpulan dari kepercayaan atau adat istiadat, melainkan sesuatu yang telah lebih dulu disatukan dengan sistem yang telah disusun secara jelas sebelumnya.

h. Kultur adalah sesuatu yang bersifat adaptif. Artinya adalah kultur merupakan proses bagi suatu kelompok dengan tujuan untuk membangun hubungan baik dengan lingkungan tempat tinggalnya, sehingga semua anggota yang terlibat berusaha dengan maksimal untuk bertahan hidup dan melanjutkan keturunan mereka.

Dalam ajaran Islam sikap multikultural ini tercermin dalam QS. Al
Hujurat: 13. Berdasarkan surah tersebut manusia memang telah diperintahkan untuk saling menghargai dan memahami setiap perbedaan yang ada.

SMA Islam Bawari merupakan sekolah swasta terakreditasi A terletak di Jl. Merdeka Barat No 173, kec. Pontianak Kota, Kota Pontianak. SMA tersebut merupakan salah satu sekolah Islam di Pontianak. Peserta didik di sekolahan ini memiliki keberagaman seperti perbedaan status sosial, suku, dan budaya. Mayoritas etnis peserta didik disana adalah Melayu dan Jawa. Minoritas etnis Dayak dan Madura.

Permasalahan yang terjadi di lapangan antara lain seperti peserta didik yang saling mengejek mengenai status sosial, perbedaan budaya, perbedaan suku, warna kulit, dan bahkan perbedaan antar bahasa. Perbedaan seperti ini meskipun dianggap sebagai candaan biasa tetapi jika sering dilakukan akan mengakibatkan perpecahan dan pertikaian kecil yang lambat laun akan menjadi masalah besar antar individu. Hal ini akan mengakibatkan persatuan menjadi memudar.

Melalui pendidikan sejarah yang memiliki kaitan dengan pembentukan watak bangsa yang mengedepankan asas Pancasila, diharapkan tidak ada perselisihan antara minoritas dengan mayoritas etnis sehingga terciptanya rasa toleransi serta kesetaraan antar perbedaan etnis, budaya maupun kebiasaan dari setiap peserta didik. S.K Kochar (2008: 27-37) mengatakan ada setidaknya lima hal yang didapat dengan mempelajari sejarah, yaitu:

1. Mengembangkan pemahaman tentang diri sendiri. Sejarah perlu diajarkan untuk mengetahui siapa diri kita sendiri dengan diperlukannya perspektif sejarah. Setiap orang tentu memiliki warisan yang unik dan berbeda-beda, kombinasi antara tradisi ras, suku, kebangsaan, keluarga, dan individu. 
2. Memberikan gambaran yang tepat tentang konsep waktu, ruang dan masyarakat. Konsep ini berkaitan erat dengan masyarakat dan sangat penting kaitannya dengan masa sekarang. Bahasa, tradisi dan berbagai kebiasaan yang saat ini hanya dapat dipahami melalui studi tentang pertumbuhan dan perkembangan dalam ruang dan waktu. Konflik atau perseteruan yang terjadi antar negara juga hanya dapat dipahami melalui sudut pandang sejarah politik, ekonomi, dan sosial.

3. Menjadikan masyarakat mampu mengevaluasi nilai-nilai dan hasil yang telah dicapai oleh generasinya. Sehingga sejarah membuat mereka peka terhadap berbagai macam permasalahan masyarakat, politik, sosial dan ekonomi.

4. Mengajarkan toleransi. Sejarah perlu diajarkan dengan tujuan mendidik para siswa agar memiliki sikap toleransi yang tinggi terhadap adanya perbedaan keyakinan, kesetiaan, kebudayaan, gagasan dan citacita.

5. Membantu mencarikan jalan keluar bagi berbagai masalah sosial dan perseorangan.

Menurut S.K Kochar (2008: 60-61) Sejarah memberikan gambaran kepada kita tentang masyarakat dengan keragamannya, serta kemudian mampu bertoleransi terhadap perbedaan-perbedaan yang ada dan membuat kita mampu memahami kebudayaan masa sekarang melalui penjelasan tentang asal usul segala sesuatu yang ada, adat istiadat, dan kebiasaan.

Dapat ditarik kesimpulan bahwa tujuan pembelajaran sejarah adalah untuk menyiapkan peserta didik untuk lebih mengerti makna yang terkandung dalam setiap peristiwa sejarah dan peserta didik harus mampu mengambil poin penting dari peristiwa tersebut selain itu, pembelajaran sejarah juga memberi pemahaman kepada siswa mengenai keragaman yang ada, serta menanamkan pengetahuan, sikap, dan nilainilai keragaman.

Masalah ini menjadi sebuah tantangan dan pengalaman bagi guru pendidikan sejarah SMA Islam Bawari Pontianak dalam menumbuhkan nilai-nilai multikultural dan semangat toleransi kebersamaan serta persaudaraan sehingga mampu menerapkan nilai-nilai multikultural di lembaga pendidikan.

Berdasarkan uraian singkat diatas peneliti mengambil judul penelitian tentang "Penanaman Pendidikan nilai-nilai Multikultural Dalam Pembelajaran Sejarah di SMA Islam Bawari Pontianak"

\section{METODE PENELITIAN}

Metode dalam penelitian ini yaitu penelitian kualitatif pendekatan deskriptif dengan teknik pengumpulan data dilakukan dengan observasi, wawancara, dan dokumentasi. Lokasi penelitian di SMA Islam Bawari Pontianak. Penggalian informasi dari informan ditentukan dengan teknik sampling (Purposive Sampling). Sedangkan informan yang dipilih pada penelitian ini antara lain guru, waka kurikulum, dan juga peserta didik.

Menurut Sugiyono (2011: 243) menyatakan bahwa, "Penelitian kualitatif diperoleh dari berbagai sumber dengan menggunakan teknik pengumpulan data, kemudian mendeskripsikan hasil data tersebut sesuai hasil analisanya". Penelitian ini mendeskripsikan penanaman nilai-nilai multikultural dalam pembelajaran sejarah. Mulai dari perencanaan, proses, hingga penilaian dalam menanamkan nilai-nilai multikultural dalam pembelajaran sejarah oleh guru mata pelajaran sejarah. Penelitian ini juga memaparkan kendala yang dihadapi saat menanamkan nilai-nilai multikultural dalam pembelajaran sejarah.

Pada penelitian ini bentuk analisis yang dilakukan dengan menggunakan teknik deskriptif kualitatif. Bogdan (yang dikutip dalam Sugiyono, 2017: 244) menyatakan bahwa data merupakan sebuah 
proses dalam mencari dan menyusun secara sistematis data yang diperoleh dari berbagai macam alat pengumpulan data seperti hasil dari wawancara, dan catatancatatan yang diperoleh saat di lapangan, sehingga peneliti dapat dengan mudah dipahami dan temuannya dapat diinformasikan kepada orang lain dengan baik dan jelas. Analisis data ini melalui data reduksi, penyajian dan verifikasi. Tiga tahapan dalam analisis data ini guna menetapkan kredibilitas dan keabsahan data maka perlu dilakukan pemeriksaan.

\section{HASIL PENELITIAN DAN}

\section{PEMBAHASAN}

Pemahaman Pendidikan Nilai-Nilai multikultural di lingkungan SMA Islam Bawari Pontianak

SMA Islam Bawari Pontianak adalah sekolah yang memiliki keanekaragaman, baik dari segi status sosial, etnis, dan budaya pada setiap peserta didiknya. Hal ini terlihat dari adanya beberapa peserta didik dan pendidik yang berasal dari etnis yang berbeda. Namun dari perbedaan itu lah yang menjaga persatuan dan kesatuan.

Berdasarkan data dari guru mata pelajaran sejarah pada tanggal 05 November 2019 bahwa mayoritas suku di sekolah ini adalah suku Melayu, Jawa, dan Bugis, sedangkan minoritasnya Dayak dan Madura.

\section{Keberagaman Siswa Berdasarkan Suku Melayu

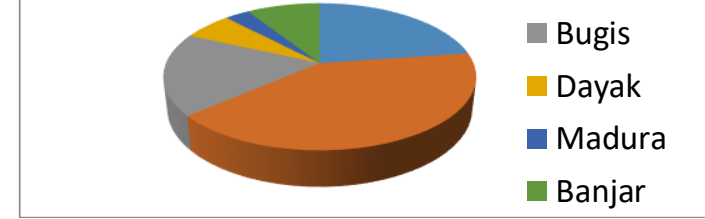

\section{Gambar 4.1}

Terkait dengan pemahaman pendidikan nilai-nilai multikultural di lingkungan SMA Islam Bawari Pontianak sudah sangat baik, karena guru selalu memberikan pemahaman kepada siswa terkait nilai-nilai multikultural, selain itu guru juga memberikan contoh teladan kepada peserta didik dalam menerapkan toleransi dan kerukunan

Skeel (yang dikutip Suparlan, 2018: 2) menyatakan bahwa "Pendidikan multikultural merupakan bentuk suatu sikap dalam memandang keunikan manusia dengan tanpa membedakan ras, budaya, serta status sosial".

Selain itu pemahaman terkait nilainilai multikultural tidak hanya dilakukan dalam proses pembelajaran saja, guru juga memberikan bimbingan dasar dalam penanaman nilai-nilai multikultural seperti yang dikatakan oleh Ibu Diah Yulianti, penanaman pendidikan nilai-nilai multikultural di SMA Islam Bawari dimulai dengan memberikan siswa bimbingan dasar seperti disiplin, sopan santun dalam berbicara dan meminta izin. Dari sinilah akan terbentuk sifat dan perilaku yang baik sehingga nilai-nilai moral bagi siswa bisa tercapai sesuai visi misi sekolah.

Dalam memahami pendidikan multikultural guru sebagai pendidik merupakan aspek utama dalam proses pembelajaran, karena tercapai atau tidaknya tujuan pembelajaran tergantung pada gurunya. Oleh karena itu, guru selalu melakukan persiapan khusus seperti, mengetahui latar belakang siswa dan kemampuan siswa sehingga nantinya dalam proses belajar mengajar tidak ada perbedaan.

Pendidikan sejarah menjadi salah satu mata pelajaran yang penting dan sangat cocok untuk memberikan pemahaman dan menanamkan nilai-nilai multikultural pada siswa. Namun dalam kenyataannya materi pendidikan sejarah yang terdapat dalam kurikulum 2013 tidak semua mengandung nilai multikultural. Oleh karena itu dibutuhkan kemampuan guru untuk dapat menyampaikan materi dengan menyisipkan nilai-nilai multikultural tersebut.

Martins, (yang dikutip Christina Chin 2008, hal. 203) menyatakan bahwa demi 


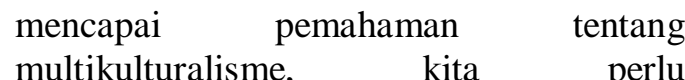
mendefinisikan dengan jelas tentang pendidikan multikulturaliisme itu sendiri. Melalui definisi yang jelas, kami dapat membuat perubahan yang diperlukan dalam kebijakan".

\section{Proses Penanaman Nilai-Nilai Multikultural dalam Pembelajaran Sejarah Kelas XI SMA Islam Bawari Pontianak.}

$\begin{array}{clr}\text { Proses } & \text { penanaman nilai-nilai } \\ \text { pendidikan } & \text { multikultural } & \text { dalam }\end{array}$ pembelajaran sejarah kelas XI SMA Islam Bawari Pontianak yang dapat dilihat dari bagaimana kegiatan pembelajaran sejarah dilakukan, kemampuan guru dalam menyisipkan nilai toleransi, kerukunan dan kesetaraan sangat baik. Hal ini terlihat saat guru mengajarkan materi kepada peserta didik.

Dalam proses pembelajarannya guru Pendidikan Sejarah sering menggunakan model pembelajaran Contextual Learning karena dianggap sangat efektif dalam menanamkan nilai-nilai multikultural dalam pembelajaran sejarah.

Dalam pelaksanaannya materi pelajaran juga mendukung proses penanaman nilai-nilai multikultural dalam pelajaran sejarah di kelas. Salah satu materi yang penulis lampirkan yaitu "Pergerakan Nasional Indonesia dan pengaruhnya pada masa kini". Materi ini banyak mengajarkan kita untuk bekerja sama, saling menghormati, menghargai, bersatu, dan banyak menanamkan nilai multikultural di dalamnya tanpa memandang perbedaan.

Selain model guru juga menggunakan metode dalam belajar mengajar. Dalam proses penanaman nilainilai multikultural guru menggunakan metode pembiasaan. Metode ini sesuai dengan konsep pengajaran sejarah di kelas maupun di luar kelas melalui kegiatan ekstrakurikuler, upacara bendera dan kunjungan lapangan.

Menurut Ngainun Naim \& Achmad Sauqi (2011: 93) terdapat beberapa pendekatan yang harus dikembangkan dalam mengajarkan pendidikan sejarah yang yang multikultural yaitu melalui pendekatan sosiologi, pendekatan historis, pendekatan kultur, pendekatan psikologis, pendekatan estetik, pendekatan perspektif gender, dan pendekatan filosofis. Dari tujuh pendekatan tersebut, guru mata pelajaran sejarah di SMA Islam Bawari Pontianak hanya menerapkan tiga pendekatan saja yaitu pendekatan historis, pendekatan kultur, dan perspektif gender.

\section{Kendala dalam Penanaman Nilai-Nilai Multikultural dalam Pembelajaran Sejarah Kelas XI SMA Islam Bawari Pontianak}

Penanaman nilai-nilai multikultural dalam proses pembelajaran sejarah di SMA Islam Bawari Pontianak sudah terlaksana dengan baik, namun tidak dapat dipungkiri bahwa dalam prakteknya masih ditemukan kendala. Kendala yang dihadapi siswa dalam pelaksanaan pembelajaran yaitu kurangnya fasilitas dalam pembelajaran seperti buku paket, keterbatasan buku paket sebagai sumber belajar ini cenderung membuat siswa malas belajar dan tidak berminat pada pelajaran tersebut. Selain itu kendala yang dihadapi oleh guru saat pelaksanaan pembelajaran juga berkaitan dengan kemampuan siswa dalam memahami karakter-karakter yang ada di dalam diri siswa tersebut.

Hal serupa juga diungkapkan oleh Ibu Nurul Utami selaku guru pendidikan sejarah terkait dengan kendala saat penanaman nilai-nilai multikultural. Kendala tersebut ialah siswa kesulitan dalam menerima dan memahami materi pelajaran dengan baik. Selain itu keterbatasan buku paket yang relevan sebagai sumber belajar turut menghambat proses penanaman nilai-nilai multikultural.

Dari penjelasan tersebut dapat disimpulkan bahwa dalam penanaman nilai-nilai multikultural pada mata pelajaran sejarah terdapat beberapa kendala. Kendala tersebut berkaitan dalam hal penerimaan dan pemahaman materi 
pembelajaran serta terbatasnya sumber belajar yang relevan untuk mendukung keberhasilan Penanaman nilai-nilai Multikultural dalam Pembelajaran Sejarah Kelas XI SMA Islam Bawari Pontianak.

Maksum (2001: 225) mengatakan bahwa aspek yang ada dalam lingkungan belajar tersebut merupakan hal penting yang mesti diubah sesuai dengan prinsip dan tujuan pendidikan multikultural, sehingga tercipta budaya sekolah yang mampu meningkatkan sikap positif peserta didik terhadap perbedaan budaya yang ada.

\section{Cara Mengatasi Kendala dalam Penanaman Nilai-Nilai Multikultural dalam Pembelajaran Sejarah SMA Islam Bawari Pontianak.}

Terkait dengan kendala dalam upaya penanaman nilai-nilai multikultural dalam pembelajaran sejarah, perlu adanya solusi yang harus dilakukan. Diungkapkan oleh Ibu Nurul Utami selaku guru sejarah, cara mengatasi kendala dalam penanaman nilainilai multikultural dengan melalui pendekatan. Pendekatan yang dimaksud itu seperti memberikan penjelasan serta pemahaman kepada siswa terkait materi yang akan disampaikan. Sebagai contoh, materi pembelajaran sejarah tentang interaksi budaya islam, hindu, dan budha. Pemaparan materi tidak hanya sekedar menyampaikan fakta-fakta saja. Para siswa juga harus dibimbing untuk memaknai peristiwa yang terjadi. Karena dalam sejarahnya bangsa Indonesia dibangun atas etnis dan agama yang beragam. Perlu adanya sikap saling menghargai, toleransi, dan kesadaran akan adanya multikultural.

Ia juga menambahkan bahwa masalah keterbatasan itu bisa diatasi dengan memanfaatkan sumber belajar yang ada terlebih dahulu dengan cara satu buku paket untuk dua orang atau satu meja satu buku. Guru dituntut untuk merencanakan sumber belajar yang baik dari hasil rancangan sendiri ataupun sumber belajar yang sudah ada di sekolah.

Dengan penanaman nilai-nilai multikultural dalam pembelajaran
Pembelajaran Sejarah membawa dampak positif pada diri peserta didik. Hal ini terbukti dengan tercerminnya sikap dan perilaku siswa yang sesuai dengan empat aspek pendidikan berbasis multikultural menurut Benyamin Molan (2015:71), yaitu

a. Belajar hidup dalam perbedaan

Telah kita sadari bahwa kita hidup dalam keberagaman suku, bahasa, agama, dan budaya. Dari adanya perbedaan itu kita dituntut untuk bisa hidup bersama dengan orang lain yang berbeda kebiasaan, kepercayaan, sudut pandang, pemikiran, budaya, etnis, agama, dan bahasa. Guru selalu menekankan bahwa di dalam keberagaman itu sebenarnya kita semua ini mempunyai persamaan, perbedaan itu ada karena sudut pandang kita dalam memandang sesuatu.

b. Membangun saling percaya

Hal ini merupakan satu aspek yang penting dalam bersosialisasi dengan masyarakat. Dengan adanya rasa saling percaya antar sesama, maka hubungan akan harmonis dan minim terjadinya konflik. Selama ini tidak pernah terjadi konflik ataupun permasalahan yang timbul karena adanya keberagaman ini, khususnya tidak pernah terjadi konflik antar etnis. Dalam kenyataannya di SMA Islam Bawari rasa saling percaya antar siswa, antar guru dan antar anggota sekolah sudah dibangun sejak lama.

c. Memelihara rasa saling pengertian

Keberagaman sudah melekat dalam diri siswa dan anggota sekolah lainnya sehingga sikap toleransi, menghargai, menghormati, dan memahami akan sebuah perbedaan sudah tertanam dengan baik. Adanya rasa saling pengertian ini terlihat dalam setiap kegiatan yang ada di sekolah. Misalkan menampilkan seni tari CIDAYU (tarian tiga etnis) dalam kegiatan sekolah. 
d. Menjunjung sikap saling menghargai (mutual respect), konflik dan rekonsiliasinir kekerasan.

Setiap umat beragama memiliki perbedaan dalam hal peribadatan, kepercayaan dan keyakinan. Oleh sebab itu ketika hidup saling berdampingan sebisa mungkin kita menghargai dan menghormati perbedaan tersebut. Dengan adanya sikap saling menghargai antar sesama maka kehidupan akan lebih harmonis, rukun, dan tidak terjadi konflik. Hal ini tertanam dalam diri peserta didik dan pendidik di SMA Islam Bawari Pontianak.

Berdasarkan hasil observasi dan wawancara yang dilakukan, penanaman pendidikan nilai-nilai multikultural dalam pembelajaran sejarah di SMA Islam Bawari Pontianak dinyatakan berhasil. Terlihat dengan diterapkannya kegiatan belajar yang menanamkan nilai-nilai multikultural dan kegiatan keagamaan berbasis multikultural serta terbentuknya keharmonisan, kerukunan di luar maupun di dalam lingkungan sekolah dan tingginya sikap toleransi yang ada pada peserta didik dan anggota sekolah lainnya. Sebagaimana diungkapkan oleh Choirul Mahfud (2010: 217) dalam bukunya yang berjudul “ Pendidikan Multikultural " ia mengatakan berhasil atau tidaknya pendidikan multikultural itu dapat dilihat ketika pendidikan itu mampu membentuk sikap dan menjadikan siswa untuk saling toleran, tidak bermusuhan, dan tidak berkonflik karena perbedaan budaya, bahasa, suku, agama, dan adat istiadat.

\section{SIMPULAN DAN SARAN Simpulan}

Berdasarkan hasil penelitian tentang penanaman nilai-nilai multikultural dalam pembelajaran sejarah kelas XI SMA Islam Bawari Pontianak, terdapat temuan-temuan yang dapat disimpulkan sebagai berikut:

1. Pemahaman pendidikan nilainilai multikultural di lingkungan
SMA Islam Bawari Pontianak sudah sangat baik, dikarenakan guru selalu membimbing siswa dalam memahami nilai-nilai multikultural di sela-sela pembelajaran, guru juga memberikan bimbingan dasar dalam memahami nilai-nilai multikultural di lingkungan sekolah serta adanya kegiatan keagamaan yang berbasis multikultural.

2. Proses pembelajaran pendidikan nilai-nilai multikultural dalam pembelajaran sejarah kelas XI SMA Islam Bawari Pontianak dilakukan pada dua tempat, pertama di dalam kelas melalui pembelajaran sejarah dengan menyisipkan nilai-nilai multikultural menggunakan model Contextual Learning dan metode pembiasan. Kedua di luar kelas, melalui kegiatan ekstrakurikuler, upacara bendera, dan kunjungan lapangan.

3. Kendala dalam penanaman nilainilai multikultural dalam pembelajaran sejarah kelas XI SMA Islam Bawari Pontianak. hasil dari wawancara diatas bisa disimpulkan beberapa kendala yang dialami oleh guru dan murid saat penerapan pendidikan multikultural di SMA Islam Bawari Pontianak. pertama, kendala yang dialami siswa yaitu kurangnya fasilitas dalam belajar mengajar seperti keterbatasan buku paket sebagai sumber belajar. Kedua, kendala yang dialami guru yaitu berkaitan dengan kemampuan siswa dalam memahami karakter-karakter pada diri siswa itu sendiri.

4. Solusi dalam mengatasi kendala dalam penanaman nilai-nilai multikultural diatasi dengan memanfaatkan sumber belajar yang ada terlebih dahulu dengan 
cara membagi buku, yaitu satu buku paket untuk dua orang. Selain itu guru juga membimbing peserta didik untuk memahami nilai-nilai multikultural dalam pembelajaran sejarah di kelas Saran maupun diluar kelas.

1. Bagi guru sejarah

Dalam proses pembelajaran sejarah, guru adalah pelaku utama dalam pelaksanaan proses pembelajaran. Oleh karena itu guru harus mampu menentukan model dan metode tepat karena hal itu merupakan salah satu penentu berhasil atau tidaknya tujuan pembelajaran. Selain itu pendidik dituntut untuk memiliki wawasan pengetahuan yang luas agar dapat mengembangkan materi agar pembelajaran tidak monoton dan membosankan serta dapat memperdalam pengetahuan siswa.

2. Bagi sekolah

Adanya kesadaran dalam memenuhi kebutuhan belajar mengajar terutama sumber belajar agar pembelajaran berjalan dengan lancar dan efisien dalam menanamkan nilainilai multikultural.

3. Bagi peneliti

Bisa dijadikan rujukan untuk penelitian yang berkaitan dengan penanaman nilai-nilai multikultural. Kemudian peneliti selanjutnya bisa mendapatkan data yang relevan sesuai dengan hasil penelitian terkait nilai-nilai multikultural di SMA Islam Bawari Pontianak.

\section{DAFTAR RUJUKAN}

Christina, Chin. 2013. Key Dimenaions of a Multicultural Art Education Curriculum. (Journal) (Online). (International Journal of Education \& the
Arts).

http://www.ijea.org/v14n14/. Diakses pada (19 Juni 2020, pukul 23.28 WIB).

Hakim dan Sri Utari. 2018. Pendidikan Multikultural. Malang: Madani Media. Liliweri, Alo. 2005. Prasangka dan Konflik (Komunikasi Lintas Budaya Masyarakat Multikultural). Yogyakarta: PT LKiS Printing Cemerlang.

Mahfud, C. 2014. Pendidikan Multikultural. Yogyakarta: Pustaka Belajar.

Maksum, Ali. 2001. Pluralisme dan Multikultualisme Paradigma Baru Pendidikan Agama Islam di Indonesia. Yogyakarta: Aditya Media Publishing.

Molan, Benyamin. 2015. Multikultural (Cerdas Membangun Hidup Bersama yang Stabil dan Dinamis). Jakarta Barat: PT Indeks.

Ngainum, N. \& Sauqi, A. 2008. Pendidikan Multikultural, Konsep dan Aplikasi. Yogyakarta: Arruz Media.

Sugiyono. 2017. Metode Penelitian Pendidikan Pendekatan Kuantitati, Kualitatif, dan $R$ $\& D$. Bandung: Alfabeta.

Tilaar, H. A. R. 2014. Multikulturalisme, Bahasa Indonesia, dan Nasionalisme dalam Sistem Pendidikan Nasional. (Jurnal) (online). http://jurnal.uinjkt.ac.id/inde x.php/dialektika/article/dow nload/6287/3821. Diakses pada (19/7/2019, pukul $10.15 \mathrm{WIB})$.

Wibowo, A. M. 2018. Multikulturalisme Peserta Didik Muslim di Yogyakarta. (Jurnal) (online). http://jurnaledukasikemegag.o rg. Diakses pada (19/3/2019, pukul 00.15 WIB). 